\title{
Analisis Debit Banjir Rancangan menggunakan Metode HSS Nakayasu di Sungai Tulang Bawang Provinsi Lampung
}

\author{
Mirnanda Cambodia ${ }^{(1)^{*}}$, Moch. Iswan Hasan ${ }^{(2)}$, Elza Novilyansa ${ }^{(3)}$ \\ ${ }^{(1)}$ Universitas Sang Bumi Ruwa Jurai, ${ }^{(2)}$ Universitas Sang Bumi Ruwa Jurai, ${ }^{(3)}$ Universitas Sang Bumi Ruwa \\ Jurai \\ email korespondensi: mirnanda.cambodia.mc@gmail.com ${ }^{1 *}$
}

\begin{abstract}
Abstrak.
Banjir pada Sungai Tulang Bawang terjadi karena sungai tidak dapat menampung volume debit air yang disebabkan oleh curah hujan yang tinggi maupun musiman dan populasi penduduk di Kabupaten Tulang Bawang yang semakin meningkat dengan tingkat perekonomian yang masih sangat kurang menyebabkan tata guna lahan bantaran sungai menjadi permukiman penduduk. Dengan demikian,penelitian ini bertujuan untuk menganalisis besarnya debit banjir rancangan kala ulang $\mathrm{Q}_{2}$ th, $\mathrm{Q}_{5}$ th, $\mathrm{Q}_{10}$ th, $\mathrm{Q}_{20}$ th, $\mathrm{Q}_{25}$ th, $\mathrm{Q}_{50}$ th dan $\mathrm{Q}_{100}$ th. Metode yang pertama dilakukan dalam perhitungan hujan maksimum daerah menggunakan metode Polygon Thiesen, kemudian dilakukan analisis distribusi frekuensi terhadap data curah hujan menggunakan metode distribusi probabilitas Log Pearsen III lalu diujikesesuaian distribusi frekuensi dengan metode Chi-Square dan Smirnov- Kolmogorov. Metode analisis untuk mendapatkan debit banjir rancangan kala ulang menggunakan Metode Hidrograf Satuan Sintetis (HSS) Nakayasu. Sehinggadidapat hasil analisis debit banjir rancangan kala ulang $\mathrm{Q}_{2}$ th sebesar 427.10 $\mathrm{m}^{3} /$ detik, $\mathrm{Q}_{5}$ th sebesar $631.29 \mathrm{~m}^{3} /$ detik, $\mathrm{Q}_{10}$ th sebesar $797.07 \mathrm{~m}^{3} /$ detik, $\mathrm{Q}_{20}$ thsebesar $999.64 \mathrm{~m}^{3} /$ detik, $\mathrm{Q}_{25}$ th sebesar $1045.96 \mathrm{~m}^{3} /$ detik, $Q_{50}$ th sebesar $1262.56 \mathrm{~m}^{3} /$ detik dan kala ulang $\mathbf{Q}_{100}$ th sebesar $1508.82 \mathrm{~m}^{3} /$ detik.
\end{abstract}

Kata Kunci: Banjir, Tulang Bawang, Log Pearsen III, Nakayasu

\begin{abstract}
.
Floods in the Tulang Bawang River occurred because the river could not accommodate the volume of water discharge caused by high and seasonal rainfalland the population in Tulang Bawang Regency which was increasing with an economic level that was still very lacking causing land use along the river to become residential areas. Thus, this study aims to analyze the magnitude of the design flood discharge during the return period $Q_{2}$ th, Q $Q_{5}$ th, $Q_{10} t h, Q_{20} t h, Q_{25} t h, Q_{50}$ th dan $Q_{100 t h}$.The first method is to calculate the maximum regional rainfall using the Polygon Thiesen method, then analyze the frequency distribution of the rainfall data using the Log Pearsen III probability distribution method and then test the suitability of the frequency distribution using the Chi-Square and Smirnov-Kolmogorov methods. The analytical method to obtain the design flood discharge at the return period uses the Nakayasu Synthetic Unit Hydrograph Method (HSS). So that the results of the analysis of the design flood discharge during the return period $Q_{2}$ th are $427.10 \mathrm{~m}^{3} / \mathrm{second}, Q_{5}$ th is $631.29 \mathrm{~m}^{3} / \mathrm{second}$, Q Q 10 th is $797.07 \mathrm{~m}^{3} / \mathrm{second}$, Q 20 th is $999.64 \mathrm{~m}^{3} / \mathrm{second}$, Q Q 25 th is $1045.96 \mathrm{~m}^{3} / \mathrm{second}$, Q Q $1262.56 \mathrm{~m}^{3} / \mathrm{second}$ and the $Q_{100}$ th return period is $1508.82 \mathrm{~m}^{3} / \mathrm{second}$.
\end{abstract}

Keywords: Flood, Tulang Bawang, Log Pearsen III, Nakayasu

\section{PENDAHULUAN}

Kabupaten Tulang Bawang secara geografis terletak antara $3^{\circ} 50^{\prime}-3^{\circ} 40^{\prime}$ LS dan $104^{\circ} 58^{\prime}-105^{\circ} 52^{\prime}$ BT dan terletak pada 2 bagian hilir sungai besar yaitu Way Tulang Bawang dan Way Mesuji. Dengan pertumbuhan penduduk di Kabupaten Tulang Bawang yang semakin meningkat dan faktor pemicu tingkat perekonomian penghasilan masyarakat yang belum cukup maka daerah disekitar Sungai Tulang Bawang menjadi pilihan mayarakat untuk menjadi permukiman dengan konsekuensi rawan banjir. Sungai Tulang Bawang memiliki panjang total $96.07 \mathrm{~km}$, dengan luas daerah tangkapan sebesar $1468.75 \mathrm{~km}^{2}$. Sungai Tulang Bawang merupakan sungai terbesar ke 4 yang ada di bawah pengawasan Balai Besar Wilayah Sungai Mesuji Sekampung di Provinsi Lampung.

Berdasarkan data dan informasi diatas menyebutkan bahwa Sungai Tulang Bawang mengalami bencana banjir setiap tahun pada musim penghujan sehingga menimbulkan dampak kerugian bagi masyarakat disekitar sungai dan pemerintah daerah setempat. Dengan demikian, perlu adanya analisis untuk mengetahui besaran debit banjir yang terjadi kala ulang sebagai informasi kepada 
pihak terkait dalam perencanaan maupun penanggulangan banjir disekitar Sungai Tulang Bawang.

\section{Banjir}

Banjir merupakan hadirnya air disuatu kawasan luas sehingga menutupi permukaan kawasan tersebut dimana daratan yang umumnya kering/ daerah bukan rawa menjadi tergenang oleh luapan atau limpasan air, yang biasanya disebabkan karena curah hujan yang tinggi dan kondisi topografi wilayah berupa dataran rendah. Selain itu, terjadinya banjir juga dikibatkan oleh limpasan air permukaan (runoff) yang meluap dan volume debit air melebihi kapasitas sistem pengaliran drainase atau aliran sungai. Sehingga dapat didefinisikan bahwa banjir dapat disebabkan juga oleh rendahnya kemampuan infiltrasi tanah, sehingga menyebabkan tanah tidak mampu menyerap air. Naiknya permukaan air lantaran curah hujan yang diatas normal, perubahan suhu, tanggul/ bendungan yang jebol, mencairnya salju, dan terhambatnya aliran air dilokasi lain dapat menyebabkan terjadinya banjir (Ligak, 2008)

\section{Daerah Aliran Sungai (DAS)}

Daerah Aliran Sungai merupakan suatu hamparan kawasan yang dibatasi oleh pembatas topografi (punggung bukit) yang berfungsi untuk menerima, mengumpulkan air hujan, sedimen, dan unsur hara serta mengalirkannya melalui anak sungai dan keluar pada satu titik.

Karakter DAS bentuk memanjang dan sempit membuat laju aliran permukaan lebih kecil dibandingkan karakter DAS bentuk melebar/ melingkar. Kejadian ini disebabkan karena waktu pemusatan DAS yang berbentuk memanjang akan lebih lama jika dibandingkan DAS berbentuk melebar, sehingga terjadinya pemusatan air dititik kontrol akan lebih lambat serta dapat berpengaruh untuk laju dan volume aliran permukaan. Selain bentuk juga dapat mempengaruhi pada aliran permukaan jika terjadi hujan yang tidak serentak dikawasan DAS, namun pergerakannya terjadi dari ujung satu ke ujung yang lainnya. DAS yang memanjang membuat laju aliran menjadi lebih kecil dikarena aliran permukaan yang disebabkan hujan pada hulu belum sampai pada titik kontrol ketika aliran permukaan dari hujan di hilir sudah habis ataupun mengecil. Sementara pada DAS yang melebar, saat sampainya aliran permukaan dari keseluruhan titik di DAS tidak banyak, yang dimaksud air dari hulu sudah sampai sebelum aliran di titik kontrol mengecil/ habis (Suripin, 2004).

\section{Pengukuran Hujan}

Jumlah besaran hujan sangat penting karena mempengaruhi sistem DAS untuk itu besaran hujan adalah masukan (input) yang utama kedalam satu DAS, maka pengukuran harus dilaksanakan dengan teliti. Yang dimaksud jumlah hujan adalah keseluruh hujan yang terjadi dalam DAS tersebut kemudian akan dialihragamkan (transformed) menjadi aliran di sungai. Kebutuhan data hujan merupakan besaran hujan yang terjadi di kawasan DAS. Besaran hujan didapat dari beberapa stasiun pengukur hujan dengan cara perhitungan tertentu akan menghasilkan perkiraan hujan DAS. (Sri Harto, 2000).

\section{Metode Rata-rata Aljabar}

Besaran hujan DAS diperoleh dari ratarata aljabar, dengan cara merata-ratakan dari semua data hujan yang ada dalam DAS. Cara ini dipandang hasilnya kurang teliti karena cara yang dilakukan paling mudah, terlebih pada kawasan yang variabilitasnya sangat tinggi seperti halnya di negara kita indonesia. Cara ini dianggap wajar karena sama sekali tidak mendapatkan bobot yang berbeda disetiap stasiun, sementara jelas bahwa disetiap stasiun itu sumbangan terhadap hujan DAS pasti berbeda. Persamaan hujan DAS ini diperoleh dengan cara:

$=1 \Sigma \mathrm{H}$

Dengan:

$$
\begin{aligned}
\mathrm{H}_{\mathrm{d}} & =\text { hujan DAS }(\mathrm{mm}) \\
\mathrm{H}_{\mathrm{i}} & =\begin{array}{l}
\text { hujan masing-masing stasiun } \\
\text { (mm) }
\end{array} \\
\mathrm{N} & =\text { jumlah stasiun }
\end{aligned}
$$




\section{Metode Isohyet}

Garis isohyet adalah garis yang menghubungkan titik-titik dalam suatu DAS yang mempunyai kedalaman hujan yang sama. Dimana garis ini biasanya diperoleh dengan interpolasi data antar stasiun. Jika jumlah stasiun di dalam dan disekitar DAS terlalu sedikit, maka interpolasi menjadi sulit sehingga bila jaringan sangat jarang maka garis isohetnya dapat menjadi sangat subyektif. (Sri Harto, 2000).

\section{Hidrometri}

Debit aliran sungai (Q) adalah jumlah air yang mengalir melalui tampang lintang sungai tiap satuan waktu, yang biasanya dinyatakan dalam meter kubik per detik (m3/dtk). Debit sungai, dengan distribusinya dalam ruang dan waktu merupakan informasi penting yang diperlukan dalam perencanaan bangunan air dan pemanfaatan sumber daya air. Mengingat bahwa debit aliran sangat bervariasi dari waktu ke waktu maka diperlukan data debit pengamatan dalam waktu panjang. (Triatmodjo, 2013). Debit di suatu lokasi di sungai dapat diperkirakan dengan cara berikut:

a. Pengukuran di lapangan (di lokasi yang ditetapkan),

b. Berdasarkan data hujan,

c. Berdasarkan data debit dari stasiun di dekatnya,

d. Berdasarkan pembangkitan data debit.

Pada pembuatan stasiun pengamatan atau dengan mengukur debit, parameter yang harus diukur adalah tampang lintang sungai, elevasi muka air serta kecepatan aliran. Debit aliran dihitung dengan mengalikan luas tampang dan kecepatan aliran. Untuk mendapatkan hasil yang teliti, lebar sungai dibagi menjadi sejumlah pias, dan diukur kecepatan aliran pada vertikal di setiap pias. (Triatmodjo, 2013).

\section{METODE PELAKSANAAN}

Beberapa data dan informasi sekunder diantaranya adalah sebagai berikut:

a. Peta Administrasi lokasi penelitian di Sungai Tulang Bawang b. Peta Penggunaan lahan di Sungai Tulang Bawang

c. Peta lokasi pos pengamatan hidrologi di Sungai Tulang Bawang

d. Peta RTRW Sungai Tulang Bawang

e. Data pencatatan curah hujan di Sungai Tulang Bawang dengan durasi pencatatan minimal 10 tahun

f. Data pengamatan kondisi Sungai Tulang Bawang, dan data terkait pencatatan kejadian banjir beserta dampaknya di sekitar Sungai Tulang Bawang

Berdasarkan data dan informasi sekunder yang telah diperoleh, akan dilakukan tahapan-tahapan kegiatan analisis sesuai dengan kriteria dan pedoman analisis data perhitungan banjir rancangan dari SNI dan atau NSPM yang berlaku. Tahapan kegiatan analisis data diantaranya adalah sebagai berikut:

1. Rekapitulasi data pencatatan curah hujan dari Pos Pengamatan yang terdekat dengan Sungai Tulang Bawang

2. Analisis data curah hujan harian maksimum di setiap Pos Pencatatan Curah Hujan

3. Analisis peta jaringan hidrologi dan pembuatan Polygon Thiesen pada Sungai Tulang Bawang

Berdasarkan parameter hidrologi yang diketahui, maka akan dilakukan kegiatan analisis debit banjir rancangan sesuai dengan kala ulang menggunakan metode hydrograf satuan sintetis Nakayasu dengan tahapan sebagai berikut :

a. Analisis dan perhitungan hujan daerah maksimum pada SungaiTulang Bawang

b. Analisis uji konsistensi data curah hujan daerah maksimum

c. Analisis distribusi frekuensi terhadap data hujan daerah maksimum Sungai Tulang Bawang

d. Analisis dan pemilihan penggunaan metode distribusi frekuensi (Log Pearson Type III)

$$
\begin{aligned}
& \text { e.Analisis dan } \\
& \text { pengujian } \\
& \text { kesesuaian distribusi } \\
& \text { frekuensi terhadap }
\end{aligned}
$$




$$
\begin{aligned}
& \text { data hujan daerah } \\
& \text { maksimum Sungai } \\
& \text { Tulang Bawang } \\
& \text { menggunakan } \\
& \text { metode Chi - Square } \\
& \text { f. Analisis dan } \\
& \text { pengujian } \\
& \text { kesesuaian distribusi } \\
& \text { frekuensi terhadap } \\
& \text { data hujan daerah } \\
& \text { maksimum Sungai } \\
& \text { Tulang Bawang } \\
& \text { menggunakan } \\
& \text { metode Smirnov - } \\
& \text { Kolmogorov } \\
& \text { g.Analisis dan } \\
& \text { penentuan curah } \\
& \text { hujan rancangan } \\
& \text { Sungai Tulang } \\
& \text { Bawang } \\
& \text { h.Analisis dan } \\
& \text { perhitungan curah } \\
& \text { hujan efektif dengan } \\
& \text { parameter tutupan } \\
& \text { lahan sebagai } \\
& \text { koefisien pengaliran } \\
& \text { (Nilai C) }
\end{aligned}
$$

$$
\begin{aligned}
& \text { i. Analisis } \\
& \text { dan perhitunga } \\
& \mathrm{n} \text { debit } \\
& \text { banjir } \\
& \text { rancangan } \\
& \text { dengan } \\
& \text { Hidrograf }
\end{aligned}
$$

\begin{abstract}
Satuan
Sintetis

Nakayasu

j. Analisis debit banjir rancangan untuk kala ulang $Q_{2} t h$, $Q_{5}$ th, $Q_{10} t h, Q_{20} t h, Q_{25} t h, Q_{50} t h$ dan $Q_{100}$ th.
\end{abstract}

\section{HASIL DAN PEMBAHASAN}

Data pencatatan yang diperoleh dari Unit Hidrologi - Balai Besar Wilayah Sungai Mesuji - Sekampung, ada beberapa Pos Hujan yang berada di sekitar Daerah Aliran Sungai Tulang Bawang di titik penelitian adalah sebagai berikut:

Tabel 1. Stasiun Hujan di Sungai Tulang Bawang

\begin{tabular}{ccc}
\hline No & $\begin{array}{c}\text { Nama Pos } \\
\text { Pengamatan Hujan }\end{array}$ & Periode Data \\
\hline 1 & PH 09 - Way Awi & $\begin{array}{c}2009-2020=12 \\
\text { tahun } \\
2009-2020=12 \\
\text { tahun }\end{array}$ \\
2 & R 111 - Rumbia & $\begin{array}{c}\text { 2009- 2020 }=12 \\
\text { tahun }\end{array}$ \\
3 & R 208 - Menggala & $2009-2020=12$ \\
& & tahun \\
\hline
\end{tabular}

Analisis dan perhitungan curah hujan maksimum daerah pada Sungai Tulang Bawang dilakukan berdasarkan luas pengaruh setiap pos hujan yang terdapat di sekitar titik penelitian pada Sungai Tulang Bawang dengan menggunakan analisis perataan pengaruh berupa polygon Thiesen.

Tabel 2. Luas Pengaruh Pos Hujan Sungai Tulang Bawang

\begin{tabular}{cccc}
\hline No. & Nama Pos Pengamatan Hujan & Luas Pengaruh $\left.\mathbf{( K m}^{\mathbf{2}}\right)$ & $\mathbf{\%}$ \\
\hline 1 & PH 09 - Way Awi & 159,08 & 10,83 \\
2 & R 111 - Rumbia & 46,45 & 3,16 \\
3 & R 208 - Menggala & 724,25 & 49,31 \\
4 & R 260 - Purwa Jaya & 538,97 & 36,7 \\
\hline & Total & $\mathbf{1 0 0 , 0 0}$ \\
\hline
\end{tabular}

Tabel 3. Debit Banjir Rencana di Lokasi Penelitian pada Sungai Tulang Bawang Menurut Kala Ulang - Metode HSS Nakayasu

\begin{tabular}{llllllll}
\hline & $Q_{2 \text { th }}$ & $Q_{5 \text { th }}$ & $Q_{10 \text { th }}$ & $Q_{20 \text { th }}$ & $Q_{25 \text { th }}$ & $Q_{50 \text { th }}$ & $Q_{100 \text { th }}$ \\
\hline $\mathbf{Q}$ & 427,10 & 631,29 & 797,07 & 999,64 & 1045,96 & 1262,56 & 1508,82 \\
\hline
\end{tabular}




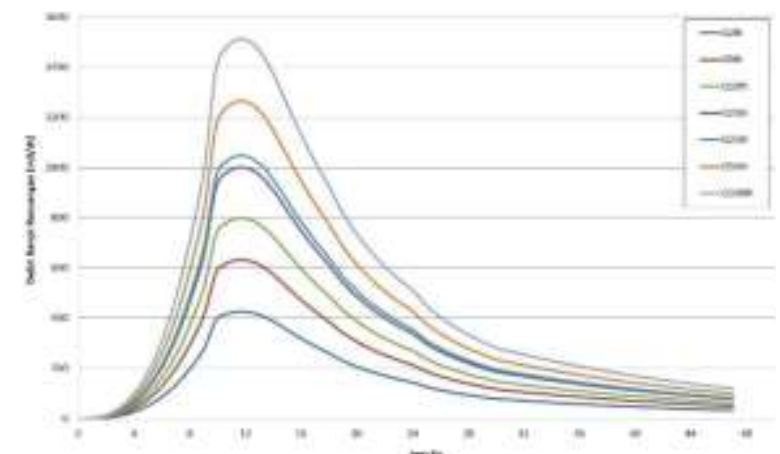

Gambar 1. Hidrograf Banjir Rencana HSS Nakayasu di Lokasi Penelitian Sungai Tulang Bawang

\section{KESIMPULAN DAN SARAN}

Sesuai dengan hasil analisis dan perhitungan debit banjir di lokasi penelitian pada Sungai Tulang Bawang yang telah dilakukan menggunakan metode HSS Nakayasu, dapat diperoleh kesimpulan debit banjir rancangan kala ulang $Q_{2}$ th sebesar $427,10 \mathrm{~m}^{3} /$ detik, $Q_{5}$ th sebesar 631,29 $\mathrm{m}^{3} /$ detik, $Q_{10}$ th sebesar 797,07 $\mathrm{m}^{3} /$ detik, $Q_{20}$ th sebesar 999,64 $\mathrm{m}^{3} /$ detik, $Q_{25}$ th sebesar 1.045,96 $\mathrm{m}^{3} /$ detik, $Q_{50}$ th sebesar $1.262,56 \mathrm{~m}^{3} /$ detik dan kala ulang $Q_{100}$ th sebesar $1.508,82 \mathrm{~m}^{3} /$ detik. Dengan melihat nilai debit banjir rancangan kala ulang $Q_{100 t h}$ cukup besar, maka perlu persiapan perencanaan penanggulangan bencana banjir yang cukup matang dan sebagai paramater sudah dapat diambil dari nilai debit banjir $Q_{50} t h$.

\section{DAFTAR PUSTAKA}

Balai Besar Wilayah Sungai Mesuji Sekampung. 2015. Dokumen Pola Pengelolaan Sumber Daya Air Wilayah Sungai Mesuji - Tulang Bawang.

Harto, Sri. 1993. Daerah Aliran Sungai (catchment area, basin, watershed): Yogyakarta

Ariyanto, Lilik. 2020. Penerapan Hidrograf Satuan Pada Daerah Aliran Sungai Way Pisang Di Kabupaten Lampung Selatan : Teknika Sains Universitas, Sang Bumi Ruwa Jurai;
Nainggolan, J., dkk, 2015. Pengaruh perubahan tata guna lahan terhadap peningkatan jumlah aliran permukaan Pengaruh perubahan penggunaan lahan terhadap debit banjir di lokasi Sub DAS Siak bagian hulu.

Suherman H., dan Firmansyah A. 2017. Pengaruh perubahan tata gunalahan terhadap debit banjir di lokasi Bagian hilir aliran kali angke.

Widyaningsih, Iin Widiatni. 2008. Pengaruh Perubahan Tata Guna Lahan di Sub DAS Keduang Ditinjau Dari Aspek Hidrologi : Wonogiri. 